\title{
Internal mammary lymph nodes identification from isolated sternum of human cadaver ${ }^{1}$
}

\author{
Identificação de linfonodos da cadeia mamária interna em esternos isolados \\ de cadáver humano
}

\author{
Luiz Gonzaga Porto Pinheiro², Paulla Vasconcelos Valente ${ }^{3}$, Paulo Henrique Walter Aguiar ${ }^{3}$, Fabrício de Sousa Martins ${ }^{4}$, \\ Leonardo Adolpho de Sá Sales ${ }^{4}$, Thiago Almeida Barroso ${ }^{4}$, José Wilson Benevides de Mesquita Neto ${ }^{4}$, Renato Santos de \\ Oliveira Filho 5
}

1. Research performed at Saul Goldenberg Laboratory. Mother and Child Health Department. Faculty of Medicine, Federal University of Ceará (UFC). Fortaleza, Brazil.

2. PhD, Associate Professor, Head of Breast Division, UFC. Fortaleza, Brazil.

3. Fellow Master degree, UFC. Fortaleza, Brazil.

4. Graduate Student, UFC. Fortaleza, Brazil.

5. Visiting Associate Professor, Coordinator of Sentinel Lymph Node Laboratory of Plastic Surgery Division and Plastic Surgery PostGraduation Program, Federal University of São Paulo (UNIFESP). Brazil.

\begin{abstract}
Purpose: To identify the lymph nodes positioned along the internal mammary vessels in isolated sternum of human cadaver and to standardize the surgical approach to those nodes, in order to establish anatomical landmarks to be used with the current techniques of mammary gland sentinel lymph node detection. Methods: Ten sternum plates removed from unclaimed cadavers were used in this study. Sternal plates were removed using bilateral incisions of the ribs at the midclavicular lines. The characterization of the internal mammary vessels and the anatomical integrity of the parietal pleura were indispensable requirements during the procedure. Results: A total of 29 lymph nodes were removed from the 2nd (13) and the 3 rd (16) intercostals spaces. Almost $50 \%$ of all nodes collected were located medially to the vessels. Conclusion: The approach used is a reliable surgical technique for removing lymph node from sternal plates. The model is therefore valuable for breast surgeons training in sentinel node biopsy, an important procedure for breast cancer patients.
\end{abstract}

Key words: Breast Neoplasms. Mammary Arteries. Lymph Nodes. Sentinel Lymph Node Biopsy.

\section{RESUMO}

Objetivo: Identificar os linfonodos localizados ao longo dos vasos mamários internos em esternos isolados de cadáveres e padronizar a abordagem cirúrgica desses linfonodos, registrando os pontos de reparo a serem utilizados nas técnicas atuais de pesquisa do linfonodo sentinela da mama. Métodos: Estudaram-se dez esternos isolados de cadáveres humanos. Os esternos foram obtidos através de secção bilateral do gradil costal ao nível das linhas hemiclaviculares. A individualização e a integridade anatômica da pleura parietal e dos vasos mamários internos foram requisitos imprescindíveis durante a dessecação das peças. Resultados: Um total de 29 linfonodos foram removidos do $2^{\circ}$ e $3^{\circ}$ espaços intercostais (13 e 16 linfonodos respectivamente). Quase $50 \%$ dos linfonodos removidos se situavam em posição medial aos vasos mamários. Conclusão: A abordagem cirúrgica usada neste estudo demonstrou ser uma técnica adequada para a exérese de linfonodos esternais. Conclui-se assim que o modelo utilizado se presta ao treinamento para o procedimento de biópsia de linfonodo sentinela, de grande valor na abordagem das pacientes portadoras de câncer da mama.

Descritores: Neoplasias Mamárias. Artérias Torácica Interna. Linfonodos. Biópsia de Linfonodo Sentinela.

\section{Introduction}

As from 1995 to 2000 the incidence of female breast cancer has increased $1.5 \%$ annually ${ }^{1}$. This rate is greater in developing countries than in others due to the increase in life expectancy and behavior change resulting in more exposure to risk factors. Lymph node staging has been carried out during initial patient approach in developed countries. Around $20 \%$ to $30 \%$ of all breast cancer cases are diagnosed quite early (in situ lesions) with negative axillary nodes in $79 \%$ of the patients at this stage. ${ }^{2}$ These values are somewhat different in developing countries where more than $50 \%$ of the cases are diagnosed at advanced stages of the disease. Late stages (III and IV) of breast cancer are seen in $60 \%$ of women who seek medical attention at the Breast Unit of Federal University of Ceará. Lack of adequate surveillance programs, the reduced number of specialists and the small number of educational programs may account for these so high percentages of advanced breast cancer. Increased survival rates have been reported lately. According to Parkin ${ }^{3}$, in Europe the overall survival rate is $91 \%$ after the first year and 65\% after five years in Europe. Such rates in the United States increase to $96.8 \%$ after the first year. As primary prevention of breast cancer is not available as yet, early detection and treatment in the initial phase of the 
disease are, therefore, the most important measures for its control. ${ }^{4}$ Available diagnosis methods include mammography, breast ultrassonography, sentinel lymph node biopsy, and fineneedle aspiration biopsy among others. ${ }^{5,6}$ Sentinel lymph node biopsy along with those diagnosis methods ensure means for adequate staging of the illness and the therapeutic approach. Currently, it is admitted that the presence of metastatic lymph nodes is the main predictor factor for prognosis of the breast malignant neoplasia course being the basis of therapeutic program. The involvement of axillary and / or internal mammary chain lymph nodes is associated with worsened prognosis in breast cancer. So, lymph nodes status is essential for staging breast cancer. In the recent past emptying of the axillary lymph nodes was required for this matter, resulting in a series of additional complications ${ }^{7}$. Sentinel node biopsy is an appropriate initial alternative to routine staging axillary lymph node dissection for patients with early-stage breast cancer with clinically negative axillary nodes. ${ }^{8}$ The discerning knowledge of anatomy is the appropriate way for definition of surgical landmarks that allow adequate access to a given anatomical area. For that reason the purpose of this paper is to identify the location of the lymph nodes positioned along the internal mammary vessels and to standardize the surgical approach to those nodes, in order to establish anatomical landmarks to be used with the current techniques of sentinel lymph node detection. In most cases where indicated, surgeons do not approach internal mammary lymph node because of surgical difficulty.

\section{Methods}

Ten formaldehyde preserved isolated human cadaver sternum plates provided by the Morphology Laboratory of the Federal University of Ceara were used (Figure 1). The sternum plates were removed from unclaimed cadavers by sectioning the ribs along the midclavicular lines. The subcutaneous tissues and the posterior pleura were preserved. The internal mammary vessels could be easily visualized by transparency. A basic box of dissection instruments containing surgical dissecting forceps, scalpel and knives, Metzenbaum scissors, Farabeuf retractors, hemostatic Kelly and Crile forceps and bone rongeur for periosteum were used. Anterior parasternal access at the level of the 2nd and 3rd intercostal spaces was used to expose the rib cartilages and the

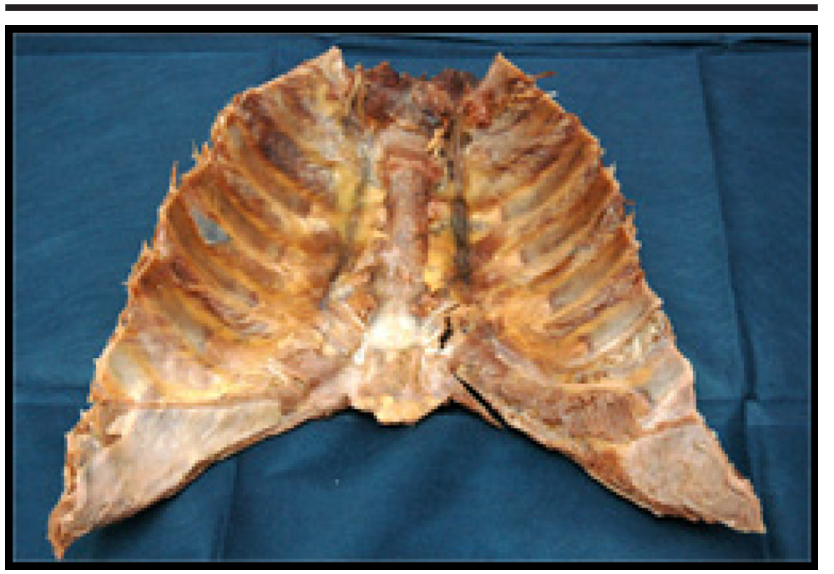

FIGURE 1 - Human cadaver sternum plate used for lymph node dissection sternocostal articulations of the 2 nd and 3rd ribs. The first stage of the dissection consisted of detaching the pectoralis major muscle from its attachments to the manubrium and sternal body, exposing the sternocostal joints. ${ }^{9}$ Upon identification and detachment of the intercostal muscles from the ribs special attention is paid to the neurovascular structures located at the superior border of the intercostal space surgically accessed (Figure 2). The thoracic vessels (internal mammary artery and vein) are covered by connective tissue and the endothoracic fascia. This anatomical layout provides a natural cleavage plane for easy surgical separation of the parietal pleura, posterior located, form the thoracic wall. ${ }^{10}$ Preservation of the anatomical integrity of the parietal pleura is an essential requirement for a successful internal mammary lymph node dissection.

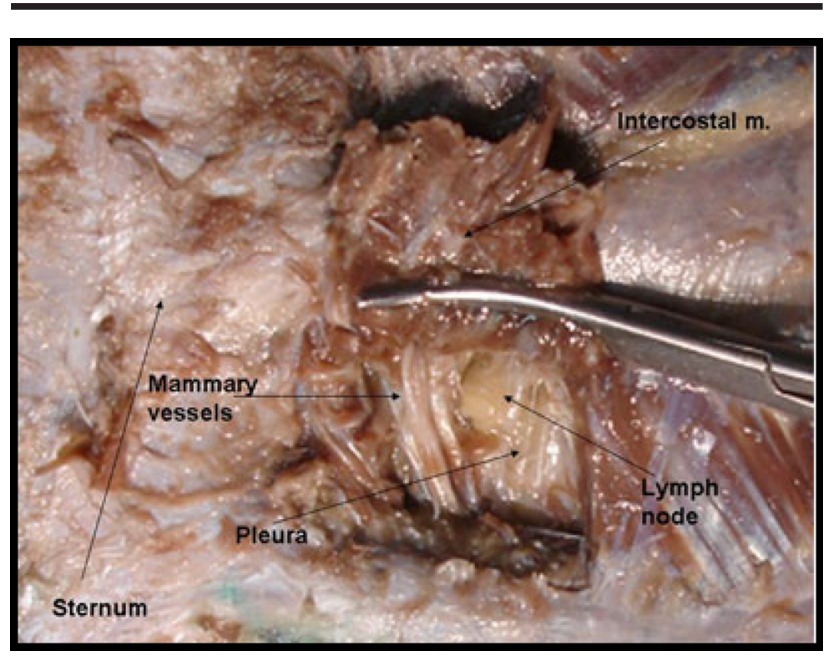

FIGURE 2 - Identification of the anatomical structures

\section{Results}

Forty intercostal spaces were dissected from the 10 specimen corresponding to the $2^{\text {nd }}$ and $3^{\text {nd }}$ intercostal space. Out of such 40 intercostal spaces, 29 lymph nodes were removed for histological study. Overall average was 2.9 nodes per sternum plate. Parietal pleura lesions were identified in two instances. The lymph node total count dissected was 18 on the right side and 11 on the left side for both second and third intercostal spaces. The results are summarized below (Figure 3).

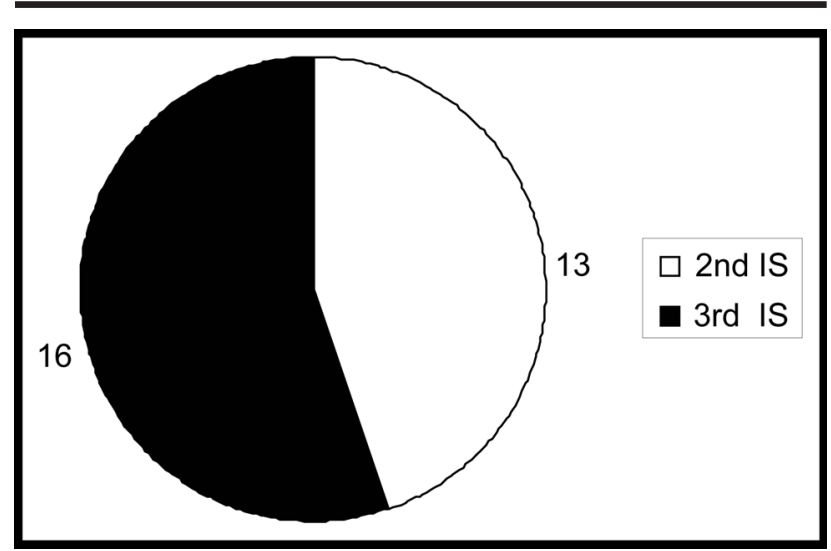

FIGURE 3 - Total Lymph node count in the 2nd and 3rd intercostal spaces 


\section{Discussion}

Axillary lymph node drainage is the main spreading pathway for breast cancer. Halsted was the first to describe it and to emphasize the importance of axillary emptying in patients with breast cancer - with or without lymphatic metastases. His work emphasis was the development of the radical mastectomy procedure named after him. His technique was the standard treatment for breast cancer for almost a hundred years (1873-1960). Approximately 25\% of breast cancer drains to the internal mammary chain. ${ }^{11,12}$ Halsted was well aware of this pathway as expressed in one of this assertive: "I think that in the near future we should remove the mediastinal content in some of our primary surgical procedures". ${ }^{13}$ The first report of surgical exploration of the anterior mediastinum along with removal of internal mammary lymph nodes appeared in the beginning of the last century. Positive lymph nodes were found in two patients out of a total of six cases reported. A second report, by the same author, described the removal of the internal mammary lymph node chain in five breast cancer patients. According to the author the surgical procedure lacked feasibility. ${ }^{13}$ Handley ${ }^{14}$ published a large series of internal mammary lymph node dissection in 500 patients. The overall incidence of positive nodes was $31 \%$ for lesions located in the inner quadrant of the breast and $19 \%$ in external quadrant lesions. Lacour et al. ${ }^{15}$ demonstrated that the surgical removal of the internal mammary chain lymph nodes as an isolated factor increases the disease free interval from $52 \%$ up to $71 \%$ in patients with positive axillary lymph nodes and $\mathrm{T} 1$ or $\mathrm{T} 2$ primary tumors arising in the inner quadrant of the breast. These techniques were abandoned for the increase of morbidity and death rates without significant increase of patient's recovery from disease. Lymph node distribution and spread along the internal mammary vessels depicted in figures 4-5 followed a similar pattern to findings of Abrão and Neto ${ }^{16}$. These researchers studied the rate of occurrence and distribution of the internal mammary lymph nodes in the intercostals spaces. The authors reported an average of 8.9 and 7.3 lymph nodes on the right and left side of sternal plates, respectively. The nodes were located for the most part in the first three intercostals spaces. ${ }^{16}$

The application of the concept of sentinel lymph node for clinical stages I and II neoplasias, allowed a less aggressive access to the axilla. ${ }^{5,6}$ The use of technetium to detect areas of possible axillary lymphatic drainage has gained generalized approval for providing a less aggressive approach to those nodes. In Italy, where the sentinel lymph node research began in axilla of breast cancer patients, the approach to the internal mammary chain lymph nodes has been initiated. ${ }^{7}$ Gaffney ${ }^{17}$ has stated that inner quadrant breast lesions carry a worse survival rate compared to external quadrant lesions. He believes that such results are related to poor lesion staging and inadequate therapy in cases where internal mammary lymph nodes were not removed for proper examination. For that reason he advises breast surgeons to approach the internal mammary chain lymph nodes in women with inner quadrant breast lesions. Marks et al. studied the anatomic relation between internal mammary lymph nodes and the suprasternal notch to facilate the design of radiation fields intended to include specific internal mammary nodal areas. They concluded that the caudal portion of the third costochondral interspace is $<$ or $=11 \mathrm{~cm}$ caudal to the suprasternal notch in $90 \%$ of patients. These measurements can be used to clinically design radiation therapy fields intended to treat the upper three interspaces ${ }^{18}$. Galimberti et al (2002) removed internal mammary lymph nodes in 182 patients either if there was radiouptake or the tumor was located in the medial portion of the breast. There were migration from N0 (4 cases) or N1 (10 cases) to N3, prompting modification of both local (radiotherapy to internal mammary chain) and systemic treatment. These patients would be understaged without internal mammary lymph node sampling ${ }^{19}$. The use of an intercostal window for the approach of internal mammary lymph nodes as described here provides a safe way to proper identification and removal of these nodes. As internal mammary lymph nodes are located medially or laterally to the thoracic wall arteries, a careful lymph node dissection prevents the lesion pleural, a dreadful complication of this surgical procedure. The present model should be useful for training breast surgeons in the pursuit and safe removal of the sentinel lymph node.

\section{Conclusion}

The procedure here described provides a safe approach to the internal mammary lymph nodes. Careful dissection of the lymph nodes located medially or laterally to the mammary vessels averts the pleural lesion, a dreadful complication of this surgical procedure. The present model should be useful in training breast surgeons in internal mammary sentinel lymph node biopsy.

\section{References}

1. Parkin D. Global cancer statistics in the year 2000. Lancet Oncol. 2001; 2: 533-43.

2. Holland JF, Frei E, Kufe DW, Bast RC. Principles of medical oncology. 6.ed. Philadelphia: Saunders; 2001.

3. Parkin DM, Bray FI, Devesa SS. Cancer burden in the year 2000: the global picture. Eur J Cancer. 2001;37:S4-66.

4. Instituto Nacional do Câncer. Estimativas da incidência e mortalidade por câncer no Brasil em 2006. [cited 2006 June 23]. Available from: URL: http://www.inca.gov.br/ estimativa/2006/index.asp

5. Moore MP, Kinne DW. Is axillary lymph node dissection necessary in the routine management of breast cancer? Yes. Important Adv Oncol. 1996; 12: 245-50.

6. Morton DL, Ollila, DW. Critical review of the sentinel node hypothesis. Surgery. 1999; 126: 815-9.

7. Veronesi U, Paganelli G Niale G, Galimberti V, Luini A, Zurrida S, Robertson C; Sacchini V, Veronesi P, Orvieto E, De Ciccio C, Intra M, Tosi G, Scarpa D. Sentinel lymph node biopsy and axillary dissection in breast cancer: results in a large series. J Natl Cancer Inst. 1999; 91:368-73.

8. Lyman GH, Giuliano AE, Somerfield MR, Benson AB 3rd, Bodurka DC, Burstein HJ, Cochran AJ, Cody HS 3rd, Edge SB, Galper S, Hayman JA, Kim TY, Perkins CL, PodoloffDA, Sivasubramaniam VH, Turner RR, Wahl R, 
Weaver DL, Wolff AC, Winer EP; American Society of Clinical Oncology guideline recommendations for sentinel lymph node biopsy in early-s tage breast cancer. J Clin Oncol. 2005;23(30):7703-20.

9. Williams PL, Bannister LH, Berry MM, Collins P, Dyson M, Dussek JE, Ferguson MWJ. Gray's anatomy: the anatomic basis of medicine and surgery. 38ed. London: Livingstone; 1995.

10. Gardner E, Gray DJ, O’Rahilly R. Anatomia: estudo regional do corpo humano. 4ed. Buenos Aires: Salvat; 1988.

11. Turner-Warwick R. The lymphatics of the breast. Br J Surg. 1959;46:574-82.

12. Weiss L, Gilbert HA., Ballon SC. Lymphatic system metastasis. Boston: G. K. Hall; 1980.

13. Haagensen, MD. Diseases of the breast. 3 ed. Philadelphia: Saunders; 1986.

14. Handley RS. The early spread of breast carcinoma and its bearing on operative treatment. Br. J. Surg. 1964;51:206-8.
15. Lacour J, Bucalossi P, Cacers E, Jacobelli G, Koszarowski T, Le M, Rumeau-Rouquette C, Veronesi U. Radical mastectomy versus radical mastectomy plus internal mammary dissection: five-year results of an international cooperative study. Cancer. 1976;37:206-14.

16. Abrão A, Neto JBS. Estudo anatômico da cadeia ganglionar mamária interna em 100 casos. Rev Paul Med. 1954; 45:317-21.

17. Gaffney DK, Tsodikov A, Wiggins CL. Diminished survival in patients with inner versus outer quadrant breast cancers. J Clin Oncol. 2003; 21:467-72.

18. Marks LB, Bentel GC, Hardenbergh PH, Lind PA, Prosnitz LR. A locate the first three internal mammary lymph practical and easy method to node: bearing areas. Int J Radiat Oncol Biol Phys. 2001;50(2):421-5.

19. Galimberti V, Veronesi P, Arnone P, De Cicco C, Renne G, Intra M, Zurrida S, Sacchini V, Gennari R, Vento A, Luini A, Veronesi U. Stage migration after biopsy of internal mammary chain lymph nodes in breast cacner patients. Ann Surg Oncol. 2002;9(9):924-8.

\section{Correspondence:}

Luiz Gonzaga Porto Pinheiro

Surgery Department

Rua Prof. Costa Mendes, 1608/3 andar

60430-140 Fortaleza-CE Brazil

Phone: (55 85)3366-8063

Fax:(55 85)3283-7851

luizgporto@uol.com.br
Conflict of interest: none Financial source: none

Received: July 05, 2006

Review: August 13, 2006

Accepted: September 18, 2006

\section{How to cite this article:}

Pinheiro LGP, Valente PV, Aguiar PHW, Martins FS, Sales LAS, Barroso TA, Mesquita Neto JWB, Oliveira Filho RS. Internal mammary lymph nodes identification from isolated sternum of human cadaver. Acta Cir Bras. [serial on the Internet] 2006 Nov-Dec;21(6). Available from URL: http://www.scielo.br/acb. 